\title{
Paul Ricoeur e a narrativa além do gênero discursivo
}

\author{
Leticia Cantarela Matheus' \\ https://orcid.org/0000-0002-2860-2607 \\ I - Universidade do Estado do Rio de Janeiro. \\ Rio de Janeiro (RJ), Brasil.
}

Resumo: O artigo desenvolve uma reflexão teórica sobre o conceito de narrativa do filósofo francês Paul Ricoeur (1913-2005), tendo por objetivo articular elementos que permitam pensar este conceito para além dos limites de um gênero discursivo. A hipótese é que seus argumentos, na construção do conceito de tríplice mimese, podem ser considerados e aplicados como um modelo metafórico para o processo comunicacional, mesmo considerando que Ricoeur não estava pensando na comunicação.

Palavras-chave: narrativa; comunicação; discurso; Ricoeur.

Abstract: Paul Ricoeur and the narrative beyond discursive genre - The paper unfolds a theoretical argument on the concept of narrative by the French philosopher Paul Ricoeur (1913-2005), aiming to intertwine elements that allow us to think about this concept beyond the limits of one discursive genre. The hypothesis is that his arguments, in constructing the concept of triple mimesis, can be considered and applied as a metaphorical model for the communicational process, even considering that Ricoeur was not addressing communication studies.

Keywords: narrative; communication; discourse; Ricoeur.

A leitura do mundo precede a leitura da palavra. (Paulo Freire)

\section{Introdução}

Este artigo discute o conceito de narrativa do filósofo francês Paul Ricoeur (1913-2005), tentando escapar a um quadro que o tratasse como um tipo de 
discurso ou uma qualidade particular da linguagem. A proposta é entender esse conceito como operador teórico para análises de comunicação em vez de inscrevê-lo em uma perspectiva ontológica segundo a qual o pesquisador seria obrigado a identificar quais textos são narrativos ou não. Como se trata de uma perspectiva interdisciplinar, assumimos o risco que o esgarçamento excessivo de um conceito, para além das bases teórico-filosóficas que o produziram, neste caso, a hermenêutica, pode fragilizá-lo e causar desconforto entre especialistas, neste caso filósofos, ao verem a narrativa ricoeuriana "aplicada" a uma ciência social. O artigo procura pistas espalhadas pela obra do autor, como ele mesmo fez em relação à teoria do discurso (2005, p. 23), para defender que seu conceito de narrativa serve como modelo comunicacional, na esperança de ajudar os pesquisadores a construir seus métodos com base na hermenêutica de Ricoeur. ${ }^{1}$

O primeiro ponto é que, enquanto filósofo, Ricoeur discutiu conceitos filosoficamente. Ele não era um analista social, seu conceito de narrativa não nasce de base empírica. Como ele mesmo diria (RICOEUR, 2012, p. 42), seu compromisso era com ética, não com a ciência. Isso não significa que não possamos devolver sua narrativa ao campo da experiência empírica. Disso decorre o segundo ponto, que é o fato de estarmos tomando a narrativa como ferramenta teórica, não como algo de natureza ontológica. Narrativa se apresenta, aqui, como objeto teórico, não como objeto empírico ("isto é uma narrativa; isto não é"). Essa premissa desobriga o pesquisador tanto a realizar uma taxonomia dos discursos quanto a se limitar ao texto escrito como seu corpus empírico, ou mesmo à linguagem verbal, ampliando o escopo das textualidades que podem ser submetidas à pesquisa social, por exemplo, como faz Louzada (2013), ao tratar fotografias como narrativa.

Tecendo a intriga, a fotografia organiza de forma bidimensional elementos dispersos no tempo e no espaço, soltos no universo, ininteligíveis como unidades fragmentadas. É tecendo a intriga que é dado sentido às diversas formas narrativas [...] que metaforizam a vida e o mundo. (LOUZADA, 2013, p. 162)

No caso de Louzada, o que a autorizou empiricamente a realizar essa aproximação com o conceito de narrativa de Ricoeur foi a adoção dos instantâneos pelos jornais cariocas na década de 1950, que instauram a ideia de 
movimento e também a prática do jornal carioca Última Hora de publicar sequências de imagens - como um cinema impresso - , o que também dava a sensação de fluxo temporal. É nessa linha de apropriação que queremos tratar Ricoeur, para analisar processos comunicacionais.

Ricoeur falou explicitamente de comunicação duas vezes. A primeira em congresso temático em 1971 (RICOEUR, 2005), no Canadá, e depois repetiu o núcleo de sua definição em uma obra em 1976 (RICOEUR, 2000):

A comunicação é um enigma e até mesmo um milagre. Por quê? Porque o estar junto, enquanto condição existencial de possibilidade de qualquer estrutura dialógica do discurso, surge como modo de ultrapassar ou de superar a solidão fundamental de cada ser humano. (RICOEUR, 2000, p.27-28)

Ele explica que essa "solidão" é aquilo que é experimentado, mas que não pode ser transferido para outra pessoa:

\begin{abstract}
Um acontecimento que pertence a uma corrente de consciência não pode se transferir como tal para outra [...]. E, no entanto, algo se passa de mim para vocês, algo se transfere de uma esfera de vida para outra. Este algo não é a experiência [...] mas sua significação. Eis o milagre. A experiência [...] permanece privada, mas o seu sentido se torna público. A comunicação é, deste modo, a superação da radical incomunicabilidade da experiência. (RICOEUR, 2000, p. 27-28)
\end{abstract}

Apesar de esse trecho apresentar uma visão bastante ampla sobre a comunicação, é preciso lembrar que o entendimento que o autor tinha de comunicação se dava por diálogo com a linguística. Ele tomava como base a filosofia analítica da língua, considerava que um discurso possuía um sentido e se preocupava com uma teoria do discurso, embora também levasse em conta a linguagem não-verbal dentro de um quadro limitado que ele chamava de discurso oral. Nessa obra (RICOEUR, 2000), as brechas que ele abre para o mundo "fora do texto" ainda são limitadas: quando incorpora o ato de fala e quando se preocupa com a intenção do discurso em uma dimensão ética do indivíduo (RICOEUR, 2005, p. 24). Esse quadro se ampliaria mais tarde, em obras posteriores a 1976.

Portanto, não se pode afirmar que haja processo social em Ricoeur relacionado ao problema que ele coloca sobre a comunicabilidade. O que nos permite desenvolver essa conexão se encontrará no conceito mais tardio 
de tríplice mimese, desenvolvido na publicação original de 1983 (Temps et Récit, tomo I), de cuja versão brasileira de 1994 pegamos algumas pontas, tais como o fato de a referência, para ele, ser uma projeção que o mundo do texto lança, e que não dependerá somente de uma coerência interna da narrativa. É seu conceito de narrativa que será tomado emprestado aqui como modelo teórico do processo comunicacional e que funcionará como síntese para pensar uma série de teorias fundamentais para tratar de linguagem na Comunicação (pragmática do discurso, estética da recepção, hermenêutica, fenomenologia etc).

\section{A tríplice mimese}

Quando optamos operacionalmente pela narrativa, não há a obrigação de usar Ricoeur, nem como fundamentação teórica nem para dele extrair categorias e estratégias de análise. No entanto, percebe-se atualmente grande ansiedade em adotar o autor em pesquisas em Comunicação pelo fato de ele ter se popularizado no Brasil e ser muito citado sobretudo em trabalhos que tratam da narrativa (BARBOSA, 2006, 2007; RESENDE, 2009; MOTTA, $2005,2008,2013)$. Muitas vezes, parece difícil isolar pragmaticamente, em sua obra, recursos analíticos possíveis, uma vez que Ricoeur dialoga simultaneamente com muitas tradições de estudos de linguagem, indo da linguística à teoria literária, da estética da recepção à crítica da historiografia etc. Porém acreditamos que uma chave prática que costura todos esses diálogos é a articulação em torno da narrativa.

Como explica Dosse (2017), a dedicação de Ricoeur à narrativa surge como uma alternativa mais consistente aos chamados narrativistas, na luta contra o estruturalismo. Para isso, Ricoeur "restitui a pertinência de um fora-dotexto" (DOSSE, 2017, p. 434) que, na nossa opinião, constitui-se tanto no referente (aquilo do que se fala), quanto na enunciação (o ato de comunicação), quanto também no próprio sujeito da ação de comunicar, bem como todas as condições conjunturais do comunicar. Isso não significa que Ricoeur tenha abandonado ou negligenciado a estrutura interna da narrativa (a armação ou tessitura da intriga), mas é que ela não é suficiente para a compreensão (eu diria para a produção) do sentido da narrativa.

Apesar de lutar contra o estruturalismo, Ricoeur não apresenta preconceito contra ele. Para o autor, a análise estrutural pode até mesmo ser realizada, desde que depois devolvamos o "texto" ao universo da experiência. Trazendo 
para nosso universo da Comunicação, seria o mesmo que dizer que uma análise propriamente linguística poderia ser aceita como uma etapa inicial da pesquisa, como análise "de conteúdo", desde que esses resultados depois sejam analisados à luz do processo integral de comunicação, isto é, desde que lembremos que a linguagem pertence ao mundo social. Foi exatamente o que propôs Ricoeur. Seu empreendimento foi justamente juntar hermenêutica e fenomenologia, promovendo uma espécie de hermenêutica da vida, central para as ciências sociais (ALBERTI, 1996; GADAMER, 1999, DILTHEY, 2010).

Ricoeur (2012) foi o primeiro a se adiantar na própria crítica e dizer que essa transição (das técnicas de análise do texto para as técnicas de análise da vida) deve ser feita com cautela. No entanto, ele admite: "O texto é uma analogia" (RICOEUR, 2012, p. 55). Ele seria uma metáfora da ação significante, entendendo que não damos sentido apenas a textos, sons e imagens, mas a coisas, pessoas, acontecimentos, lugares, práticas, tecnologias, ao tempo, enfim, a tudo. É nessa ponta da costura que é possível alinhavar perspectivas mais sociológicas. Isso porque nem a hermenêutica que Ricoeur propõe é uma exegese textual, nem sua fenomenologia é psicologizante. Essa possível ligação com estudos empíricos se encontra com mais clareza no conceito de tríplice mimese, como discutimos a seguir.

\section{Detalhamento da mimese}

No início do capítulo 2 de Tempo e Narrativa tomo I, Ricoeur (1994, p. 55) explica porque convoca a ideia de narrativa de Aristóteles (2003), tão importante para ele que estava preocupado com uma teoria da ação (no caso da referência a Aristóteles, metaforizada na performance teatral). A partir de Aristóteles, Ricoeur entende que a narrativa possui duas dimensões: o muthos (acontecimento) e a mimese (ação). Isto é, o muthos (aquilo que foi falado) seria o resultado da performance de falar (a ação significativa), como o "braço movido" e "mover o braço" (RICOEUR, 2012, p. 61). Interessado nas “operações mediadoras entre a experiência viva e o discurso" (RICOEUR, 2012, p. 56), entendidas por nós como a própria comunicação, Ricoeur afirma que essa duplicidade da condição narrativa (muthos e mimese) ajuda a pensar a tensão dialética entre a coerência (concordância) do discurso e a complexidade da vida (discordância), o que no plano temporal, como veremos adiante, traduzir-se-á em intentio e distentio. Para ele, o muthos aristotélico seria a própria tessitura da intriga, isto é, a obra, a representação da coisa. Por outro lado, a mimese aristotélica seria a imitação da coisa, a atividade de representar, 
a distensão, no tempo, enquanto ato, da coisa imitada, sendo, portanto, de forma complementar, a contraparte discordante-concordante. Uma narrativa não existe sem suas duas partes: a performance de represent-AÇÃO e o representado. Por isso, ontologicamente, muthos e mimese não se encontram apartados, apenas, metodologicamente, apresentados separados para se pensar filosoficamente sobre a aporia do tempo (historicidade) e da narrativa (comunicação).

Ricoeur não estava tratando exclusivamente de um gênero do discurso. Segundo Dosse (2017, p. 445), a narrativa de Ricoeur "é a mediação que assegura a materialização do sentido da experiência" e que se expressa nos seguintes três níveis: “Na prefiguração prática, na configuração epistêmica e na sua reconfiguração hermenêutica" (PETIT, 1991, p. 15 apud DOSSE, 2017, p. 445). Isto é, a própria tríplice mimese já contém esse segundo nível de explicação de Ricoeur, para quem a narrativa é ao mesmo tempo, prática, forma de conhecimento e interpretação.

O filósofo desenvolve esse raciocínio tomando como base o caso específico da História, cuja relação sensível com a narrativa serve muito como lição na Comunicação. No caso da História, a narrativa é inescapável, pois o pesquisador precisa necessariamente escrever uma história (historiografia). Mais do que forma de apresentação de resultados científicos, a narrativa é parte da própria composição do argumento, mesmo quando os historiadores tentam negar que estão produzindo narrativa (DOSSE, 2017, p. 442).

Se nosso interesse é adotar a narrativa de Ricoeur como fonte de múltiplas elaborações metodológicas e mostrar que seu conceito comporta uma aproximação com um modelo teórico de comunicação, não podemos ignorar que o filósofo também considerava uma dimensão ontológica da narrativa que, na nossa opinião, é expressa sobretudo no conceito de inteligência narrativa. Como Ricoeur estava preocupado com uma hermenêutica da consciência histórica (DOSSE, 2017, p. 446), ele entendia que a narrativa também está submetida à historicidade. Portanto, é evidente que há algo de concreto no seu conceito. Isto é, se o ato de narrar é histórico, ele próprio é objeto. Mas pode também ser ferramenta.

Percebe-se que a narrativa de Ricoeur não é apenas conteúdo, mas também o ato de produzir esse conteúdo, o que a aproximaria da comunicação. Para esclarecer onde há ação, Ricoeur enfatiza a importância de se entender representação em Aristóteles como, de fato, imitação da ação, até porque 
A Poética é uma aula de teatro. Quando Aristóteles fala em mimese, ele está efetivamente falando da encenação de ações no palco. Portanto, dentro do conceito de narrativa estariam tanto a disposição, o enredamento das ações na forma do enredo (intriga), quanto a ação de representar. "Os dois termos muthos e mimese devem ser considerados operações e não estruturas" (RICOEUR, 1994, p. 58). Quero entender aqui que, com "operações", Ricoeur nos transpõe para o terreno da comunicação, não da linguística.

Mais adiante na mesma obra (RICOEUR, 1994), ele vai dizer que a intriga (a composição interna da narrativa, o enredo) se organiza sim por um tipo de coerência, que possui "completude, totalidade e extensão apropriada" (RICOEUR, 1994, p. 66). Isto é, a narrativa deve ter uma coerência interna mínima, com princípio, meio e fim, sendo uma síntese temporal. Síntese porque a linguagem sintetiza mundos, tanto no sentido de ser uma redução possível (um recorte da realidade), e necessária para se operar linguisticamente, quanto no sentido de invenção (sintetização). Ora, não é preciso pensar em formas de comunicação muito específicas que se encaixem nesse paradigma. Não enxergamos aí nenhuma obrigação de entender narrativa como um gênero discursivo, mas de aproximá-la de um leque amplo de formas de comunicação. Por outro lado, Ricoeur (1994) reconhece e defende que a narrativa não é e não pode ser pura concordância (coerência), como já dito acima. Ela possuiria também uma discordância interna, que é justamente o que permite que ela se distenda em direção ao público, ou seja, que o mundo do texto seja projetado enquanto ação no mundo social; enfim, que a narrativa seja sempre completada pelo público, como apropriação e ressignificação, caracterizando-se pelo efeito emocional e preenchimento de lacunas de significação pela experiência comunicativa. Essa distensão se dá também em relação ao tempo, uma vez que a narrativa se lança ao futuro e ao passado simultaneamente e que, por isso, permite a Ricoeur relacioná-la à própria historicidade.

Para Ricoeur (1994), a mimese abre o espaço da ficção, essa espécie fenda temporal na realidade, necessária à invenção de novos mundos, a partir da qual exercitaríamos nossa imaginação produtora. Haveria, nesse processo, um movimento de permanente reconhecimento e contiguidade com o mundo vivido. Seu pensamento por aporias pode causar angústia para quem está produzindo pesquisa empírica. Essa angústia frequentemente parte da rejeição de que é o homem quem faz a própria história e que, portanto, não haveria muita diferença, enquanto fenômeno de comunicação, entre criar 
arte e criar mundo, entre contar e fazer história. Querer manter a poética e sua capacidade imaginativa de um lado e o mundo prático de outro é perder de vista a própria função transformadora da linguagem. Existiria aí um preconceito de fundo contra a comunicação, como algo limitado ao mundo das ideias, ao mundo simbólico, como se essas dimensões não fossem pragmaticamente realizadas no mundo social e que os atos de comunicação não realizassem coisas, não fossem operadores do mundo social. E, como derivação desse entendimento, como se a Comunicação desse conta apenas de questões ornamentais da sociedade, e não fosse uma ciência social capaz de fornecer um conhecimento singular sobre a sociedade. Ricoeur (1994, p. 77) afirma que o “mundo do como-se" ${ }^{2}$, esse mundo do faz de conta, de fato liga a imaginação, esse exercício da poética, ao campo pragmático da ética.

O filósofo dá o nome de mimese I ao conjunto de referências éticas, ao espaço concreto de ação e de preocupação (tempo presente), o mundo das condições herdadas, isto é, a própria historicidade. Já a mimese Ill seria o mundo do público. O fluxo imaginativo, desta forma, iria de montante à jusante, sendo este rio imaginário a própria mediação. Essa dimensão intermediária seria a mimese II, onde estaria o exercício de composição da intriga. Nossa tendência, em princípio, seria compreender somente a mimese II como a comunicação, mas Ricoeur (1994) alerta que essa subdivisão é apenas metodológica e que as três dimensões na ação poética estão unidas, não havendo um sequenciamento temporal. Ainda assim, por que manter essa subdivisão? Qual sua função? Não seria este apenas um substitutivo ao modelo matemático emissor-canal-receptor por outro igual apenas com nomes diferentes? Na nossa opinião, essa substituição semântica não é simplesmente ornamental mas conceitual, justamente para destacar que a narrativa não é apenas concordância, uma obra acabada, coerente estruturalmente (internamente), mas que ela "se discorda", desencaixando-se permanentemente no processo comunicacional. Ela se estende no tempo, possui uma duração enquanto processo social e é essa noção fluida o que clarifica a associação que o autor faz entre narrativa e história.

No capítulo 3, Ricoeur (1994) explica detalhada e didaticamente a operação da tríplice mimese, estipulando que a mimese I (mundo pré-configurado) corresponde ao mundo vivido concreto, de onde vamos buscar referências (independentemente de estarmos produzindo uma obra de ficção ou não); 
a mimese II (mundo configurado) seria a configuração interna da obra; e a mimese III (mundo refigurado) o lugar do leitor, este operador da unidade do processo significativo da obra, onde ocorre a interpretação e reapropriação dos sentidos. A todo um arco hermenêutico completo deste Ricoeur chama de transfiguração do mundo, ou seja, ressignificação. Essa ressalva é importante, pois ele alerta para o risco de se entender esse circuito como sendo viciado, hipótese que ele afasta de antemão ao defender que a imagem metafórica ideal para seu conceito é o de uma espiral. Cada anel da espiral não retorna ao mesmo lugar. Se assim fosse, estaríamos vivendo na Idade das Cavernas, desenhando nas paredes. A história muda porque somos capazes de ressignificá-la. Ou estaríamos usando o modelo matemático de comunicação, segundo o qual o ruído é um defeito, não um milagre criativo.

Metodologicamente é preciso entender que a proposta hermenêutica de Ricoeur não está limitada à mimese II. Em nenhum momento ele reduz a hermenêutica à interpretação de texto. Ele fala de interpretação da vida. É por isso que é possível absorver a tríplice mimese como modelo comunicacional. Ela permite pensar para além do texto, incorporando dialeticamente texto-contexto-ato comunicacional. Assim, se pretendemos compreender os processos sociais de produção de sentido, necessitamos que nossos objetos estejam na história e não boiando fora dela. Nossos objetos são posicionados social e historicamente, assim como o próprio pesquisador. Não dá para suspender a própria historicidade para poder fazer pesquisa.

Muito pragmaticamente, é possível adotar este modelo para pensar a mediação entre certo estado significativo da coisa e sua posterior ressignificação, depois de um processo de comunicação, que pode ser tanto um ato isolado, presentista, quanto um longo processo. Mais especificamente, no caso de Barbosa (passim), ela incorpora Ricoeur justamente para trazer a longa duração para os estudos de comunicação. Por enquanto, gostaria apenas de ressaltar mais uma sistematização metodológica relevante em Ricoeur, que é a composição temporal interna da narrativa (tempo contado) e a duração levada para contar a narrativa (tempo do contar). A análise da estrutura temporal das narrativas, como aquelas realizadas por ele em Tempo e Narrativa // (RICOEUR, 1995), também são extremamente úteis como exemplos de aplicação metodológica.

\section{Representância}

Ao juntar em sua obra hermenêutica e fenomenologia, Ricoeur (1994) conecta tempo (1) e narrativa (2), isto é, história (1) e comunicação (2), equacionando 
o problema de entender a realidade como uma construção da percepção, um trabalho de interpretação. Para Ricoeur, a hermenêutica não é apenas um método, mas uma condição de conhecimento, pois ele entende que todo conhecimento, toda percepção, já é um ato interpretativo, ainda que em condições sociais previamente existentes e a partir de certos repertórios culturais (mimese I).

Como seu intuito era deslocar a ênfase do signo para o sentido, sua preocupação era com a semântica das ações. Ele acreditava que era preciso pensar a linguagem como aberta à penetração da história, isto é, a linguagem deveria estar aberta à inovação semântica através da metáfora e da narrativa. Ao unir a concepção de tempo de Santo Agostinho com a mimese Aristotélica, ele oferece pelo menos quatro formas de evitar uma análise de conteúdo ou de "representação". Vejamos quais são elas.

Segundo a primeira, há a suspeição do conceito de representação, enquanto simples imitação, dimensão contemplada por Ricoeur quando ele aciona o conceito de mimese de Aristóteles, porém ampliada ao pensar representação como um trabalho, uma performance, conforme já explicamos. Gagnebin (2017) defende inclusive que a tradução do termo usado por Ricoeur (récit) deveria ser narração, não narrativa, o que resolveria boa parte dos desentendimentos sobre seu conceito. Isso permitiria escapar ao conceito de representação, pois a narrativa de Ricoeur incorpora a ação de representar (performance) somada à representação (imagem) da coisa (enunciação e enunciado). É importante, então, destacar a dimensão ativa da representação. Ela é um ato.

Outra forma é entender o conceito de representação, que aparece na mesma obra, porém no tomo III. Nele, Ricoeur (1996) explica que o passado se apresenta como representância, como variação interpretativa ou imaginativa, assim como o futuro - como utopia, como duas variações imaginativas. Deste modo, a historiografia seria uma representância do passado, porque não há um sentido único e verdadeiro sobre ele. A historiografia também será elaborada por mediações narrativas sobre as quais o leitor irá produzir suas interpretações (REIS, 2013). O mesmo acontece com as mídias, ao fazerem circular totalizações mínimas - histórias - , como vestígios de uma representância passada - algo que se queira contar.

Representância seria, portanto, a forma de existir do passado no presente (assim como do futuro no presente). O passado não é representado mas 
possui uma latência de limite. Ele nunca será representado como imitação, mimese (sentido aristotélico), mas também não pode ser pura ficção. Tratarse-ia, então, de uma variação imaginativa. O referencial (o passado) seria um lugar-tenência. Quando Ricoeur (1996) fala de passado, ele está preocupado com um real inacessível. Sermos contemporâneos ao acontecimento que decidimos contar não torna mais seguro ou fidedigno seu referencial. Em ambos os casos, o referencial se encontra no lugar da fabulação, essa latência ou potência referencial, lugar-limite da representação, isto é, representância. A referência só será construída de fato pelo público quando ele identificar na história elementos da sua realidade. Portanto, há sempre um lapso temporal fenomenológico, sendo qualquer história do passado.

A terceira vantagem de Ricoeur (1994) ao tomar distância do conceito de representação é que seu substitutivo, o modelo tripartite de narrativa, coloca em cena o movimento - isto é, o tempo - e, com isso, permite uma série de soluções metodológicas, se consideradas cada uma das ações miméticas como variáveis diferentes na pesquisa empírica. Ao compor a narrativa a partir de três momentos miméticos - a prefiguração do mundo (a história herdada), a configuração do mundo (sua mediação pela linguagem num enredo, sua composição estética) e a refiguração pelo ato de leitura (interpretação, apropriação) - , Ricoeur (1994) oferece mais uma alternativa ao velho modelo matemático de comunicação que guardava um polo emissor e um polo receptor. Em Ricoeur (passim), não há pontas soltas na tessitura narrativa, pois toda ela se encontra dentro da história.

Para deixar clara essa ideia, Ricoeur (1994) oferece a metáfora conceitual da espiral, que permite visualizar a narrativa como a própria comunicação. A espiral é feita de infinitas voltas hermenêuticas (interpretativas), que nunca se tocam no mesmo lugar. O arco hermenêutico que se completa de mimese I a mimese III dá origem então a novos ciclos não viciados de significação e produção de sentido. A narrativa seria, portanto, uma obra de síntese (um trabalho de organização de heterogeneidades em uma unidade mínima de sentido, que é para Aristóteles uma unidade mínima de ação), porém ela seria um processo infinito como a própria história. A narrativa seria uma obra de síntese também no sentido de sintetizar a experiência humana. Sintetizar, então, não se encontraria apenas no sentido de aplainar heterogeneidades possíveis mas seria a própria fabulação de algo comum.

Uma chave concreta para compreender a importância que Ricoeur dava ao tempo e como entendia a narrativa como sinônimo de vida é quando ele 
relata dois momentos axiomáticos em seu pensamento: a experiência de ter em mãos as fotografias de seu pai, morto aos 25 anos e que, na imagem, permanecia mais novo que ele próprio, e a de seu filho, que ele diz ter interrompido a própria narrativa ao se matar (RICOEUR, 2009). Nesses relatos, fica clara a condição histórica da narrativa - como o próprio fazer histórico, - e simultaneamente a condição semântica da história (daí a relação entre tempo e narrativa, isto é, entre historicidade e história) mas também a percepção da condição fenomenológica do tempo. Como seu pai poderia ser mais novo que ele próprio? E como ele poderia falar (e sentir) sobre uma coisa que não existe mais, tal como o passado ou o próprio filho? ${ }^{3}$

Se o passado não é mais, o futuro ainda não é e o presente é um instante imensurável que escapa, quando falo do tempo, ele já passou, explica Ricoeur (1994), usando a concepção de memória de Santo Agostinho (2002). Então, para medir o tempo, precisamos de metáforas de movimentos dos astros, mas isso já não se trata do tempo. Santo Agostinho (2002) resolve esse problema dizendo que o tempo existe na alma. Isto é, tratar-se-ia de uma percepção, pois o tempo, na sua totalidade, só pertenceria a Deus, eterno e multidimensional. Portanto, sem a mediação da linguagem, o tempo seria mudo. Então Ricoeur (1994) vai dizer que a experiência é muda, a história é muda. Sua existência se daria apenas na alma, na forma de lembrança, saudade (passado), esperança, expectativa, medo (futuro), ou ação, intenção (da alma, uma ação do espírito intentio animi), percepção, atenção (presente).

Para Agostinho (2002), quem Ricoeur (1994) usa para construir seu conceito de tríplice mimese, a medida do tempo é a distensão da alma (distentio animi) em atos de comunicação e imaginação, podemos dizer. A 1) distensão e a 2) intensão (intenção, intensificação) têm a ver com 1) o prolongamento das ações humanas no tempo (incluindo a narrativa - cultura, conectores do tempo) e/ou 2) a intensificação do presente, como uma compressão. Portanto, o homem é passivo e ativo (sofre a história e a faz), sincronicamente (2) e diacronicamente (1).

Ao produzir uma síntese, o ato narrativo caracteriza um esforço de produzir uma concordância (sincronicidade) de dimensões ou estratos temporais discordantes (diacrônicas), heterogêneos. A eternidade, em Agostinho, seria essa coincidência última dos tempos, à qual somente Deus teria acesso. Mas Ricoeur (1994 e 1996) translada esse raciocínio para pensar a história e pega, para isso, a teoria da representação de Aristóteles. 
Assim, o muthos (narrativa) aristotélico, a intriga (enredo), seria esse esforço de impor uma concordância sobre a discordância, na composição do enredo. Ao mesmo tempo, para se avançar na intriga é preciso que o tempo se distenda na duração da obra (o tempo do contar) para que o sentido possa emergir (ou ser produzido sobre a obra enquanto experiência). A narrativa aristotélica agencia a heterogeneidade dos fatos em uma temporalidade lógica da obra (o tempo contado). Assim, entre o tempo da obra e o tempo na obra, qualquer intervalo de tempo e qualquer êxtase de tempo cabem na narrativa, porque ela é uma síntese histórica que dá a oportunidade de reconhecer o vivido e de obter prazer nesse reconhecimento (catarse). É esse processo que seria a representação, ou melhor, a representância, em Ricoeur.

Nesse sentido, diferentes linguagens podem ser entendidas como criações poéticas, invenções da alma. Podemos compreender também que cada um dos anéis da espiral narrativa é uma dobra no tempo, uma fenda temporal que se abre a cada novo ato narrativo, lançando novas possibilidades interpretativas para o mundo, isto é, dando a oportunidade de criação simbólica. A narrativa imporia uma ordem à desordem mas também o contrário, uma concordância discordante / discordância concordância.

A quarta grande contribuição do modelo teórico da tríplice mimese diz respeito à possibilidade de se desviar de uma ideia de representação enquanto reprodução fidedigna da realidade, ou com pretensão à fidedignidade, em função de onde ele posiciona o mundo do qual se fala. Na tríplice mimese ricoeuriana, o referente ocupa outro lugar. Ele obviamente ainda se encontra na mimese I, no mundo pré-dado, mas ele também é produzido pela linguagem ao ser lançado ao mundo pela ação de interpretação (mimese III).

Em Ricoeur, percepção, interpretação e referenciação não são operações exclusivas de um polo emissor ou de um polo receptor; não são ações deliberadas de dados momentos da vida, mas condições comunicacionais permanentes. Eu não escolho "agora vou pegar este livro e vou interpretá-lo". Ao abrir o olho, levantar a cabeça e olhar em volta eu já estou interpretando. A interpretação está tanto à jusante quanto à montante da narrativa. 0 mesmo ocorre com a referenciação, que não se encontra apenas ali quando procuro palavras para falar de coisas; mas está também quando eu procuro coisas para fazer referirem palavras. Nesse sentido, são as coisas que fazem as pessoas falarem; é o mundo material, não exclusivamente uma intenção subjetiva, que estaria "contida" no texto. 
De certa forma, pode-se compreender que a fenomenologia se encontrava em mimese I e a hermenêutica em mimese III, sendo a mimese II o processo de mediação comunicacional, mas, como, para Ricoeur (1994), esse ciclo não pode ser vicioso, ele coloca a hermenêutica desde a mimese I e a fenomenologia na mimese III. Assim, os três êxtases miméticos estão conectados, não sendo uma sequência cronológica. Eles são dimensões simultâneas e distendidas da experiência narrativa, ou comunicacional, como quisemos mostrar. Por isso, sua hermenêutica é uma condição existencial, não um simples recurso de interpretação de texto.

\section{Considerações finais}

Como vimos, Ricoeur condensa uma série de problemas teóricos de comunicação e ainda fornece enorme repertório de possibilidades metodológicas a serem criadas pelos pesquisadores, encontradas especialmente em Tempo e Narrativa tomo I (1994), cujos capítulos 1, 2 e 3 podem servir para iniciantes como entrada em sua obra. O que defendemos é que seu conceito de narrativa, baseado nas três dimensões miméticas, permite tratar metodologicamente a comunicação como processo. Seu conceito de narrativa obriga que nossos objetos não sejam fechados em si mesmos, mas que sejam observados no processo social, em progresso, ainda que o pesquisador realize um recorte consciente. Sua narrativa nos obriga a inserir as textualidades (mimese II) numa relação dialética de idas (mimese III) e vindas (mimese I) ao mundo social, prevenindo que os objetos "planem" sobre nossas cabeças, sem inserção histórica. Para dar um exemplo de aplicação metodológica: mimese II não precisa ser texto ou imagem. Pode ser um conjunto de interações em rede, cujos rastros foram coletados por algum software de mineração de dados. O que importa, metodologicamente, é que os objetos sejam sempre extraídos e devolvidos ao mundo social, de modo que o pesquisador procure entender o que eles significam, não se limitando a descrevê-los como faria um linguista estruturalista clássico, porque, em Ricoeur, a interpretação é condição epistemológica.

Resumidamente, a narrativa de Ricoeur apresenta cinco vantagens metodológicas: a) substituir a noção de circuito por processo, b) substituir o modelo matemático emissor-canal-receptor pela tríplice mimese, c) manipular os objetos de modo segmentado com cada mimese (mimese I = mundo social, contexto histórico; mimese $\|$ = textualidades ou sistemas semióticos complexos, mais do que simplesmente um "conteúdo"; mimese III = apropriação pelo 
público-sociedade), d) superar a ideia de "etapas", pois, como ele explica com a metáfora da espiral, todas elas se encontram simultaneamente no "mundo do texto" (a experiência é integral, sua segmentação é apenas analítica); e) admitir que o sentido é social, gerado no processo integral (arco hermenêutico completo de mimese I a III - transfiguração de sentido), não se limitando ao "conteúdo" de um produto midiático qualquer.

Assim, Ricoeur contribui para conectar texto (por exemplo, um ato de comunicação qualquer) e contexto (sociedade), devolvendo os objetos ao mundo social. Este ponto pode ser especialmente importante se pensarmos que talvez a Comunicação seja tímida demais e não se considere de fato uma ciência social com autoridade para explicar a sociedade.

Espero ter conseguido convencer o leitor de que a tríplice mimese pode ser tomada emprestada como modelo comunicacional e que estas anotações possam estimular a imaginação produtora de pesquisadores da Comunicação para elaborarem análises alinhadas à beleza do pensamento de Ricoeur.

Leticia Cantarela Matheus é pró-cientista e professora do Programa de Pós-graduação de Comunicação da UERJ. É doutora em comunicação social pela UFF.

leticia_matheus@yahoo.com.br

\section{Referências}

AGOSTINHO, S. Confissões. Livros 10 e 11. São Paulo: Martin Claret, 2002.

ALBERTI, V. A existência na história: revelações e riscos da hermenêutica. In: Estudos históricos - Historiografia, RJ, v.9, n. 17, 1996, p.31-57. Disponível em <https://cpdoc.fgv.br/ producao_intelectual/arq/413.pdf>. Acesso em: 27 jun. 2020.

ARISTÓTELES. A arte poética. São Paulo: Martin Claret, 2003.

BARBOSA, M. C. O filósofo do sentido e a comunicação. In: Conexão - Comunicação e Cultura, UCS, Caxias do Sul, v. 5, n. 9, p. 139-149, jan./jun. 2006. Disponível em: <http://www. ucs.br/etc/revistas/index.php/conexao/article/view/209/200>. Acesso em: em 27 jun.2020.

. Percursos do olhar. Comunicação, narrativa e memória. Rio de Janeiro: EdUff, 2007.

DILTHEY, W. Introdução às ciências humanas. Rio de Janeiro: Forense Universitária, 2010.

DOSSE, F. Paul Ricoeur. Os sentidos de uma vida. São Paulo: LiberArs, 2017. 
GAGNEBIN, J.M. Faute, culpabilité et dette: approche d'un concept herméneutique et éthique. Conferência de abertura. 06/nov/2017. V Congresso Ibero-Americano sobre o pensamento de Paul Ricoeur. São Leopoldo (RS): Unisinos, 2017.

ISER, W. O ato da leitura: uma teoria do efeito estético. São Paulo: Editora 34, 1996.

LOUZADA, S. Prata da Casa. Fotógrafos e fotografia no Rio de Janeiro (1950-1960). Niterói (RJ): EdUFF, 2013.

MOTTA, L. G. Análise Pragmática da Narrativa. In: BENETTI, M.; LAGO, C. (Orgs.). Metodologia de pesquisa em jornalismo. $2^{\mathrm{a}}$ ed. Petrópolis (RJ): Vozes, 2008. Disponível em <http:// www.portcom.intercom.org.br/pdfs/105768052842738740828590501726523142462.pdf>. Acesso em: 20 jun.2020.

. Jornalismo e configuração narrativa da história do presente. Niterói, UFF: Contracampo, n. $12,1^{\circ}$. sem/2005. Disponível em <http://periodicos.uff.br/contracampo/article/ view/17384/11021>. Acesso em: 20 jun.2020.

REIS, J. C. História da "Consciência Histórica" Ocidental Contemporânea: Hegel, Nietzsche, Ricoeur. Belo Horizonte (MG): Autêntica, 2013.

RESENDE, F. O Jornalismo e suas Narrativas: as Brechas do Discurso e as Possibilidades do Encontro. Revista Galáxia, São Paulo, n. 18, p.31-43, dez. 2009. Disponível em: <https:// revistas.pucsp.br/galaxia/article/view/2629/1671>. Acesso em: 27 jun.2020.

RICOEUR, P. A Crítica e a Convicção. Lisboa: Edições 70, 2009.

A memória, a história, o esquecimento. Campinas (SP): Unicamp, 2007.

Discours et Communication. Paris: L'Herne, 2005.

O Discurso da Ação. Lisboa: Edições 70, 2012.

Tempo e Narrativa. Campinas (SP): Papirus Editora, 1994, tomo I.

Tempo e Narrativa. Campinas (SP): Papirus Editora, 1995, tomo II.

Tempo e Narrativa. Campinas (SP): Papirus Editora, 1996, tomo III.

. Teoria da Interpretação. Lisboa: Edições 70, 2000.

Ensaio recebido em 12/03/2020 e aprovado em 04/06/2020. 